\title{
Was Marx right after all? A Critical Analysis of the Global Financial Crisis
}

Elmar Altvater - Professor de Ciência Política na Universidade Livre de Berlim. É autor de diversos livros e artigos nos quais estuda a evolução do capitalismo, a teoria do Estado, a política de desenvolvimento, a crise do endividamento e as relações entre economia e ecologia. Entre suas obras publicadas em português, citamos O preço da riqueza. Pilhagem ambiental e a nova (des)ordem mundial (São Paulo: Unesp, 1995).

\begin{abstract}
The crisis in which we find ourselves in 2009 was hardly anticipated in this form; perhaps it could not have been anticipated. This explains the general consternation and shakiness at the horrendous sums, which up until recently no one had believed could pass through parliaments and the governmental beaurocracies not only in Germany but also in other European countries and even in China.

No question: the monetary losses due to the financial crisis are substantial. However, compared to other crisis phenomena this might not be the worst to come. We are confronted with an energy crisis, which at present is of lesser interest, as due to the drop in general demand there is a corresponding drop in demand for energy and therefore the oil price is going down. This is likely to be a short-term phenomenon, before the oil price recovers again and the energy crisis gains momentum. The limitations of the fossil energy resources stored in the earth's crust are an immutable fact, making it necessary to prepare to use in the next future non-fossil energy resources.
\end{abstract}

\section{Keywords}

Global financial crisis, capitalism, marxian theory.

\section{Resumo}

A crise na qual nos encontramos em 2009 foi, de certa forma, um pouco antecipada; talvez não devesse ter sido antecipada, dada a consternação geral e instabilidade nos terríveis prejuízos que até recentemente ninguém acreditava que poderiam passar pelos parlamentos e burocracias governamentais, não somente na Alemanha como também em outros países da Europa, e até mesmo na China. Sem dúvida: as perdas financeiras devido à crise são substanciais. Porém, comparado a outros fenômenos de crise, este não deverá ser o pior por vir. Somos confrontados com uma crise de energia, que no momento é de interesse menor, visto que, devido à queda na demanda geral, há uma queda correspondente na demanda por energia e, portanto, o preço do petróleo está caindo. Provavelmente, este será um fenômeno a curto-prazo, antes que o preço do petróleo se recupere novamente e a crise energética ganhe força. As limitações dos recursos de energias fósseis armazenados na crosta terrestre são um fato imutável, tornado-se necessária a preparação para se usar, num futuro próximo, recursos de energias não fósseis.

\section{Palavras-chave}

Crise financeira global, capitalismo, teoria marxista. 


\section{NATURE, WORK, AND VALUE - A FOURFOLD CRISIS}

The crisis in which we find ourselves in 2009 was hardly anticipated in this form; perhaps it could not have been anticipated. This explains the general consternation and shakiness at the horrendous sums, which up until recently no one had believed could pass through parliaments and the governmental beaurocracies not only in Germany but also in other European countries and even in China. For up to now we have always made the experience that it takes months in the selfsame parliaments before they would agree on spending a few Euros on social services, such as for Hartz IV recipients in Germany.

Suddenly, the Maastricht criteria for budget policies-new debts not to exceed three percent of the GDP), which seemed to be as immutable as the Ten Commandments found in the bible,--are no longer valid. We are concerned as the government is bailing out the banks, i.e. those who are responsible for the crisis and the wage losses, and bear no relation to the reductions of income and social services forced on the working populace. All expectations of justice appear to be violated, irrespective of how they are justified. It is perhaps because of this that - paradoxically-much faith is placed in the resourcefulness of politicians and their ability to overcome the crisis with huge amounts of money. For, if they were not to succeed, the losses would be horrendous, not only in monetary terms. Capitulation in the face of crisis would be unconditional. This might explain why those who, in the course of the last years, have always criticized the financial markets and warned about their susceptibility to crises, i.e. movements critical of globalization, such as ATTAC, were not sufficiently heard by the concerned public.

The International Monetary Fund (IMF) estimates the bad loans to amount to 23.200 billion dollars, of which at least 10 percent, possibly more, will have to be written off as bad debt as they have lost value. The Bank of England is even more pessimistic than the IMF: it suggests the losses to date, i.e. the end of 2008, to amount to 3000 billion US dollars, though in April 2007 it had estimated these at a mere 1000 billion dollars.

No question: the monetary losses due to the financial crisis are substantial. However, compared to other crisis phenomena this might not be the worst to come. We are confronted with an energy crisis, which at present is of lesser interest, as due to the drop in general demand there is a corresponding drop in demand for energy and therefore the oil price is going down. This is likely to be a short-term phenomenon, before the oil price recovers again and the energy crisis gains momentum. The limitations of the fossil energy resources stored in the earth's crust are an immutable fact, making it necessary to prepare to use in the next future non-fossil energy resources. 
To this is to be added the climate crisis which will be more devastating in its effects than hitherto assumed. Just recently scientists found out that the increase of carbon dioxide in the atmosphere is not 0,9 percent per year, as assumed by the Climate Council of the United Nations (IPCC), but 3,5 percent, i.e. nearly four times higher. Thus we have to expect a faster and even more radical warming of the earth's atmosphere than previously assumed. As a consequence the sea levels will rise faster and the ice-shield at the poles will melt more drastically than hitherto assumed.

This will, in fact, result in a substantial loss of wealth greater than that caused by the financial crisis. Many people are suffering the consequences of this loss on a smaller or a larger scale. But financial losses can be reversed, and they are not lethal. But if nature is changed by global warming, if species of plants and animals are eradicated, evolutionary process are altered and impaired. These losses are irreversible. No matter how much money we would be willing to spend, we could not reverse such a process.

2009 is the year of Darwin and therefore such questions must be addressed. They can be answered with reference to the concept of the doubling of all economic processes, developed by a contemporary of Darwin: Karl Marx. In his view, all economic processes of value production are at the same time transformations of matter and energy, through which nature is both consumed and damaged. The degradation of natural resources has given rise to the current ecological crisis. The other side, however, is their integration into the world of values, of commodities, money and capital. In the thinking of neoclassical economists, this process creates a natural capital that has to be commercialized for the sake of producing returns on investments, comparable to any other financial investment. For some time this can appear to work, but not in the long run, as nature does not comply with the rules of the accumulation of capital. It is therefore no coincidence when financial crises and environmental crises, amplifying each other, interrupt the progress of everyday life through a dramatic impact created by converging or complementary forces. It is this interruption of the normality of everyday life that is called crisis by Georg Lukacs.

The crisis has a further aspect, to which is paid little attention in the industrialized world, but which is significant in Africa, Asia, and Latin America. That is the food crisis. The FAO, the Food and Agricultural Organisation of the United Nations, estimates that one billion humans, that is every sixth individual on earth, are starving. This is an enormous number and every individual fate ought to be of interest to us. But we must content ourselves with the data available. To alleviate the hunger of billions of habitants of this world the FAO wanted 
5, 3 billion US dollars direct aid from the wealthy nations. But the industrialized countries have difficulties allocating these sums to combat the worst famine and to provide access to food and clean water. At the same time billions are handed out to banks to rid themselves of "toxic" assets. One could therefore come to the following conclusion: we are in the midst of one of the most serious financial crises in the history of capitalism; we are in the midst of a food crisis, that will be the cause of death for many; we are in the midst of an energy and a threatening climate crisis, and we find ourselves in a moral crisis, scandalized by the fact that there is too little money available for the battle against hunger whilst at the same time the great banks are being bailed out. Future generations will certainly pillory the blatant injustices of the generation now responsible, even if some of them make a show of social responsibility by making tax-deductible donations to NGOs or the United Nations to ameliorate the worst effects of global hunger and demonstrate 'corporate social responsibility'. But mercy based on the generosity of private sponsors does not cure injustice, particularly when conditioned by tax rebates based on the submissions of proofs of donations, as the public sector now lacks money to finance social services.

\section{THE SPECIAL CHARACTERISTIC OF MARX'S ANALYSIS OF THE CRISIS OF CAPITALISM}

Impressed by the great and unexpected financial crisis some politicians (among them even conservative ones) admitted that the crisis theory in the Marxian tradition might contain some truth., The break-down of the subprime segment of the real estate markets in the USA, in the UK, Ireland or to a lesser extent in Spain and the bankruptcy of Lehman brothers on the 15th September 2008 really dragged the American investment banking system into the maelstrom. As a matter of fact Marx spoke of great world market 'thunderstorms'-as these would be named in the language of the nineteenth century-which would regularly shake capitalist world economy. These 'great world market thunderstorms, in which the conflict of all elements of the bourgeois process of production is being discharged' (MEW 13:156), the crises in the process of accumulation of capital, occurring with periodic regularity, does not only affect one or the other country, e.g. England as the country that is at the core of capitalism in its time, but will engulf the Continent, France, Germany and the United States. In the nineteenth century the United States did not yet play the role in world economy it does today.

The thunderstorms of the world market accompanied capitalist accumulation, whose laws were analyzed in detail by Marx in the three volumes of Capital, as well as in many other writings. In order to understand his writings 
today, it is important to keep in mind that he distinguished between the real side of the economic process, i.e. industrial capital and the industrial cycle on the one hand and the monetary aspect, i.e. interest-bearing capital on the other hand. He further considered it possible for the monetary and financial system to become partly and temporarily independent of the process of real accumulation. The origin of world market thunderstorms is sought for 'within the most superficial and abstract sphere of this process, the sphere of monetary circulation' (MEW 13: 156). But he also provided the argument that and why the independence of the financial markets, which we can also observe in the present financial crisis, can never be absolute and will thus at some point reach its limits. In the final analysis, the monetary claims of the financial sectors must always be fed by values produced by labour in the real economy as surplus value.

Consequently, Marxian theory does not assume the neoliberal doctrine of the self-evident autonomy of financial economy vis-à-vis real economy. With the help of financial innovations-these existed in the nineteenth century, even if the term was not familiar at the time-interest-bearing capital generates always new claims. Capital becomes fictitious, and if the claims on returns that are made can no longer be met, this fictitious capital will crash on its first reality test. This is what bank director Saccard and the many small stock exchange speculators in Emile Zola's novel 'Money' (1891) discovered: the value of shares can be driven up very far, but eventually the price-earning ratio becomes so unrealistic that the quotation is to be corrected downwards, with a crash, frequently in the form of a downward avalanche into a bottomless pit. The company value, the market value of monetary assets, sometimes has to be partially written off, sometimes even completely.

And there is another aspect to Marxian theory that is significant and unique, distinguishing it from liberal as well as Keynesian approaches. This is the category of the double character of labour, developed by Marx in the first chapter of the first volume of 'Capital', and then used along the overall argumentation up to the analysis of interest-bearing capital in the third volume of 'Capital'. The double character of labour, commodities, and production is a most significant discovery. With a certain amount of self-praise Marx mentions that he sees this as the vantage point of political economy, and that he has discovered this vantage point, which is doubtless the case. This vantage point determines that every economic process both has a material dimension and beyond that simultaneously has a value-related monetary and financial dimension. Taking this into account we can possibly understand the relationship between the various sides of the existing crisis: climate change, energy crisis, and food crisis are all related to the material basis of capitalist 
accumulation. The material side of production, of circulation, of transport, of reproduction of labour, demands that we feed energy and resources from nature into the economic system, as otherwise the economic processes, production as well as transport, would rapidly grind to a halt.Following the industrial revolution at the end of the eighteen century, it is in particular fossil energy which is introduced into the production process and keeps it going.

Production only takes place when goods can be exchanged for money and when a surplus value is contained in the value of commodities produced and when the value can be realised in the form of money in the course of the circulation process. Values are created, but only when the returns on advanced capital are sufficiently high, when the rate of profit is assured and when the expectations of capitalist enterprises are not disappointed. This generates flows of income. When they are transformed into monetary wealth the (financial) claims create a new category of economic agents: the monetary wealth owners. They secure their financial resources in specialist institutions, such as investment banks, savings banks. There the money assets are made to 'work', at least the illusion is created that money is 'working', as it can achieve a surplus of interest and returns. One fails to see and understand that this surplus merely results from people working in the real world and creating those values and flows of income, which are partly used to fulfil the monetary claims of the owners of capital.

The idea of money 'working' and generating 'offspring' was already criticized by Aristotle in the fourth century BC. The critique influenced the canonic prohibition of interests in the catholic world which only was relinquished in the sixteenth century. It also had an impact on Islam and the persistent prohibition of interest in the Islamic world until present. But the critique of interests and of interest bearing capital was forgotten in the course of the history of philosophy and, later, in that of economic theory, and it was only Marx who drew systematic attention to this fact by showing that the view of interest as the 'fruit of capital' has something to do with the fetish character of money. That this fetishism has not vanished until today is something we can discover on TV, when the daily stock market quotations are listed prior to the news, as if income were generated by the stock market. Yet, this is not the case: the stock market uses complex mechanisms for the redistribution of wealth produced by workers in the process of production. But this is of no interest as the fetish of money is overwhelming.

More than commodities money can become a idea, a fetish, a human artifice (fetish is derived from the Portuguese feiticio, which means 'cobbled together'), gaining power over its creator, and even worse: in money all of capitalist society is contained and exposed as false appearance - the form of capital derives from the 
form of money. These relationships were analyzed by Marx in Capital in 1867, but even in earlier writings as in the 'Grundrisse of a Critique of Political Economy' and 'Introduction to the Critique of Political Economy' of the 1850s of the nineteenth century. This is a not insignificant contribution to the understanding of money in capitalist society, as we have to acknowledge today.

It is the contradictions of the capitalist mode of production that keep the system moving. But in the course of the process of accumulation they grow more acute and eventually reach crisis points that can interrupt the development of the system. How do these crises occur? The possibility of crisis is already contained in the form of commodities and the form of money. For as goods are sold, the seller is not obliged to spend the money he has earned immediately. At this point already the market is deprived of the money which is hoarded rather than immediately spent as effective demand. The seller of a commodity eventually travels to other places and spends his income there. This will support other commodity traders in the places where he travels. But the salespeople in the original place, to which the original commodities were sold in exchange for money,cannot meet the monetary demand which they need in order to sell their commodities. The circulation of goods and money has been interrupted, since buying and selling, selling and buying can fall apart in terms of time and space.

The dissociation of buying and selling in terms of space and time becomes even more significant if we remind ourselves of the fact that money can circulate autonomously and that payment promises (debts) can circulate bridging the gap between today and tomorrow. A debtor promises the lender, from whom he borrows money, to pay this back at a specific point in time. But due to unforeseeable circumstances the debtor cannot repay his debts. Yet the creditor was relying on having the money returned to him on time and has already made further purchases on the basis of this expectation, which he will now have to cancel. Thus a chain reaction can be set off in terms of space and time. The payments and repayments no longer work as they are included in the contracts and plans of the respective agents. The mere possibility of crisis turns into bitter reality.

Many authors have explained the crises in capitalism in terms of many economic agents making their plans independently of each other, whilst being connected to each other through commodity- and payment chains, so as to affect the whole system, when somewhere something begins to slow down and grind to a halt. In the 1920s many analysts described the crises of capitalism as results of an anarchic system. The anarchy of the market in the capitalist system could best be overcome if the anarchic market were replaced by a planned economy. This was one of the arguments for the organization of capitalism (Hilferding's 
organized capitalism) or for an economic planning of capitalism both within social democracy and among communist parties belonging to the Third (Communist) International.

The reality of the crisis is more difficult to explain than the mere possibility. For, it is necessary to show systematically which causes are responsible for buyers and sellers separating, for purchases and sales falling apart. Without doubt the most significant contradiction for the functioning of the accumulation process is the one between the power of consumption and the power of production, between the value created by the workers and what they can buy back from the returned quota of value as wage. Within capitalism the power of production undergoes a process of almost unlimited expansion, since every single capitalist hopes that he will be able to market more and thus make more profit, the more he produces. The power of production is thus extended, and not only that: capitalists also want to gain a competitive advantage on their competitors in different markets. This can only be achieved if the costs are reduced. So there is an effective incentive to increase levels of productivity, and one of the most convincing messages of capitalist development already delivered by Adam Smith, the founding father of political economy, is this: increased productivity leads to the increase in the 'Wealth of Nations'. Marx accepts this positive message. One only has to read the Communist Manifesto of Marx and Engels of 1848, containing an enthusiastic illustration of the advantages of capitalism over other forms of society due to progress made possible by increased productivity of work and the resulting wealth of nations.

At the same time the increase in productivity means that the technological conditions are changing and that human work is successively replaced by machines, so that under certain circumstances working people are not layed off but also made redundant. Accordingly, David Ricardo speaks of the fact that in the course of capitalist development a 'redundant population' is created. Superfluous people, particularly if these people can be found any- and everywhere, have few powers of negotiation. Trade unions are weakened in such a situation. This situation is further exploited by entrepreneurs aiming to lower wages. The power of the market sweeps aside visions of justice. Now two things can happen: on the one hand productivity increases, but the power of consumption does not follow or not to the same degree. A gap opens up between the power of production and the power of consumption, which can result in a sales crisis. This can be interpreted as overproduction or underconsumption. In the past this question has triggered theoretical skirmishes which led to different theoretical schools or theory strands on questions of crisis. Marx repeatedly emphasizes in Capital and 
elsewhere that the contradiction between the power of production and the power

of consumption represents one of the most important reasons for the recurring crises of capitalism. This contradiction has its origin in the dynamism of capitalist accumulation. Crises theories only make sense if they are related to the dynamism of the accumulation of capital. The development of the profit rate therefore has to be taken into account.

\section{CRISES AND CREDIT}

In Marx's time no developed credit system as we know it today, particularly in its globalized form, existed. Marx did provide a detailed analysis of the credit system of his times which is astonishingly modern. It constitutes the fifth section of the third volume of Capital (MEW, Marx-Engels-Werke, vol 25). Originally, Marx had only written one chapter on this topic. It is the fifth chapter of MEGA, the Marx Engels Complete Edition. But Friedrich Engels divided this chapter, covering hundreds of pages, into many individual chapters and called it Part Five.

Here Marx shows how interest turns into an autonomous source of income, while in the end being an essential part of surplus value. The ordinary capitalist thinks the interest and its returns on investment derive from the capital that was somehow invested somewhere. Marx declares this a fetish-driven conception, an illusion. Investment bankers today are the personification of that illusion which in the contemporary crisis turns out to be a misconception of the revenues of capital. The revenues, the interests and other forms of capital-income derive from the surplus value produced by labour in the 'real' economy and not from capital invested in the world of global finance. The surplus value is redistributed through complex processes, as described in the individual chapters of book five, to enable interest-bearing capital to access interest yield. A sum of capital deposited in a savings account accrues a certain amount of interest at the end of the year, and the subsequent year this interest gains interest on itself, thus turning into compound interest. The owner of monetary wealth has no idea from whence the interest rates derive or that these are created by human labour. This creates the illusion mentioned that money generates money. But even the critics of compound interest, frequently referring to Silvio Gesell's arguments, remain caught up in the fetish character of money. For they ignore the work and production processes, and therefore the capitalist character of the credit system and believe they can do away with interest and compound interest, without touching on the creation of surplus value, from which interest derives.

In this fifth section Marx further shows that interest, i.e. income stemming from interest-bearing capital, and the creation of profit in the real economy feature 
a very specific cyclical and opposing course, which repeatedly peaks in crises. For if interest of financial capital and profits of real capital derive from the same source, namely the surplus value created by the workers, interest and returns on financial capital can only grow, when profits are depressed and vice versa-unless the source of both modes of income, surplus value, is extended-by integrating new work forces into the system of employment, by increasing the intensity of labour, or by increasing productivity and by putting pressure on wages. These means of increase, however, have their limits to be found in the material and energetic dimension of the processes of production as well as in value relations, and also in the social power relations between wage labour and capital. Here again we must also take the double nature into account. At present the resource and energy restrictions are reflected in the accessibility of energy or in the carrying capacity of the atmosphere for greenhouse gas emissions. These material limits provoke a competition between the profit of the today's so called real economy and the interest in financial capital. The productive forces of labour would have to increase considerably to increase surplus in the real economy. But this is not going to be simple. For the productivity of labour is not only a matter of technology and organisation, is not simply within the power of disposal of the management, but has a social component. If the increase in productivity is linked to an increase in the intensity of labour, then the opposition of the work force will be provoked. This has led to the failure of past attempts to raise productivity and the intensity of labour. This fact has been largely accepted in the social sciences and has led to the assessment that the presently dominant model of increasing productivity, associated with the production line and the name of Ford, which is finding its end and that a 'Postfordism' is about to be created, to overcome the limits to an increase in productivity on the basis of a new technological paradigm. The limits to overproduction in industry, in real economy are indubitable, particularly if we take into account the ecological conditions of production. This can be described in greater detail than provided here, but the result will always be the same. An endless increase in real surplus to feed the financial claims is out of question.

On the other hand there are tendencies in the capitalist world economy to drive the demands of global financial markets even further. The 25 percent dream returns promised by $\mathrm{Mr}$ Ackermann (the $\mathrm{CEO}$ of Deutsche Bank) provides an exemplar of the stock market game of the 'bankocracy', mentioned by Marx. Even in Marx's times greed was the driving force of the 'character masks' on the parquet floors of the stock markets, described so impressively by Emil Zola in his novel 'Money'. Marx writes at gthe end of the first volume of 'Capital' that capital abhors the absence of profit or of very little profit, as nature abhors the 
vacuum. With sufficient profit capital becomes audacious. At least ten percent and this can be applied everywhere. 20 percent, makes it exciting and 50 percent positively adventurous, for 100 percent it will trample on the laws of humanity, 300 percent and there is no crime it will not risk committing, even when faced with the gallows (MEW 23:788).

But there are new characteristics turning the role play of the 'character masks' into an absurd one. Since the liberalization of the global financial markets in the 1970s and the collapse of the fixed currency system of Bretton Woods, exchange rates, a central value in global economy, have no longer been determined by central banks and governments or international organizations, such as the International Monetary Fund already mentioned. They are also no longer tied to the gold standard as it was in Marx's times, but they are determined by private agents in markets. This can be interpreted as a process of privatization of public goods as suggested by Egon Matzner. This tendency was encouraged by the liberalization of another crucial price regulating the global economy, i.e. the interest rates. It is no longer the central banks that determine the discount and prime rate-the agents in the financial markets have to take this as their guide-but the rate of interest is determined spontaneously by the private exchanges of large global banks, insurance companies and other financial institutions involved in the global market. The 'sovereignty of determining the interest rates' is thus lost to private agents operating in global financial markets. To make this work without a hitch the international capital markets are liberalized. This liberalization took a long time until it was nearly perfect in the early 1990s. Liberal economists see therein an increase in the efficiency of the financial system. Again, the efficiency of the financial system is seen as a precondition and basis for the efficient functioning of the economy as a whole, which eventually allows for the increase in the wealth of nations. Whoever opposes the liberalization of the financial markets opposes the increase in the wealth of the populace and is thus a reactionary. This, at least, was the generally accepted opinion prior to the occurrence of the financial crisis.

The liberalization of the financial markets may be the most significant feature of globalization. One needs to keep in mind that competition on financial markets differs from competition in normal commodity markets. There competition causes the prices to fall and quality of goods to improve. This is good for everyone, it is a win-win-game. On financial markets however financial places and financial institutions are competing, with a stable currency, with returns that are as high as possible and with the lowest possible taxes and restrictions for investors. In the wake of the liberalization of the financial and currency markets pressure is thus created not to reduce prices, as would be the case in goods markets, but to push 
interest and exchange rates up. This is why devaluations of currencies are feared and also why a strategy of undervaluation of currencies is applied to create a permanent expectation of revaluation.

The statistics in virtually all countries and for most of the time show that since the beginning of the 1980s the effective interest rates have been higher than the real growth rates of the GNP. The interest rates have been higher than the profit rates to be attained in the real economy. This is a fantastic incentive for all monetary wealth owners not to invest in the real economy creating jobs but to let the capital 'work' in the liberalized, global financial markets. This is, in fact, an illusion. But since the 1980s and the liberalization of the financial markets this seemed to work quite well at first.

But only rather. It was always a crisis-ridden process. The first major crisis occurred in the 1980s, shortly after the liberalization of the financial markets. This was the Third World debt crisis that affected all the Third World countries. First Third World countries had taken loans from private banks in the 1970s. These loans were cheap. They invested them into new factories, infrastructure etc. or used them on consumer goods, imports of technology or arms purchases. Many Third World countries were military dictatorships, particularly in Latin America. They took on loans from banks with a high level of liquidity as the oil profits had increased after the oil price shock of 1973 and the oil producing countries were able to recycle their capital to Third World countries through banks in London and New York. This was particularly opportune for the United States of America, as it allowed the American banking system to move into the centre of world finance or to improve its position there. Thus the dollar could be retained as oil currency, despite the dollar having lost in value considerably in the 1970s (in particular due to the disaster of the US in Vietnam). This favoured the global hegemony of the United States and its special relationship with oil producing countries. For Third World countries this arrangement was less advantageous. The 1980s are considered a 'lost decade' by all those countries affected by the debt crisis.

For they had their debts in dollars and the American Federal Reserve could still exert some influence, and this is precisely what Fed Chairman Volcker did in 1979- he gave the Third World what is known as the 'Volcker Shock', an increase in interest rates, which resulted in most of the Third World countries no longer being able to repay their external debts. This means that the real surplus of the economies of Third World countries did not suffice to repay the debts, the interest rates and amortizations owed to the First World financial institutions. The debt crisis broke out.

Every crisis contains an element of opportunity-a principle that also 
applies to the debt crisis of the 1980s. This was used to enforce a new political model on all the nations of the Third World and on those of the Second World (the economies of actually existing socialist countries), which still existed in the 1980s according to which they had to open up their protected economies to world markets. This forced the Third World countries to adjust to the conditions of the world market. In the so called socialist countries this led to a collapse of the planned economies and the disappearance of a Real Socialist alternative. When the Iron Curtain fell in 1989 this set the seal on a development that had started years before. It first started in December 1981 during the riots in Poland, initiated by Solidarnosc, that contributed also to debt servicing of foreign investors not being covered any more and to the coup of General Jaruzelski resulting in years of a military dictatorship in Poland. This was the first sign of the irrevocable decline of actually existing socialism.

During the debt crisis of the 1980s banks had handed out loans to states or single creditors, and now these debts had to be converted and restructured in order to escape the debt crisis. This was quite complicated but finally it succeeded. During the financial crises of the 1990s in Asia and Latin America a different procedure was adopted, compared to that of the previous decade. The then CEO of the IMF, Camdessus, rather tellingly called the financial crisis in Mexico the 'first financial crisis of the 21 st century'. For other than in the previous decade Third World loans were securitized and could thus be exchanged on the world financial markets: consequently the credit banks or fonds found it easier to rid them of loans they were not expecting repayment on. The financial markets became more flexible than in the previous decade and thus experienced an upsurge. But some crises of a more superficial nature could not be avoided in the United States, like the savings and loan crisis or the 'dotcom bubble' of the New Economy towards the end of the 1990s.

9/11 also played an important role, as the attack on the World Trade Centre caused the American Federal Reserve under Alan Greenspan to react with a radical reduction in interest rates. This was intended to contain the consequences of the disaster. This provided the basis for money that had been invested in the New Economy so far and which had not been annihilated by the burst of the bubble in $2000 / 2001$. It also provided the basis for using that money for handing out loans to home-buyers and home-builders in the US. This happened in view of the fact that in those days the Bush Administration still pursued the massive individualist policy of every American citizen having a right to their own home. From an ecological and social point of view this is a quite frightening vision, but that was the policy. This resulted in an extended property boom, which collapse is causing so much 
trouble. We shall, however, not forget that this subprime real estate crisis would not have had such a disastrous effect, if it were not bolstered by toxic bonds from credit card deals, national debts and speculation on insurance bonds.

On the global financial markets, where much money could be made, a whole range of so called financial innovations were developed and applied. In part they have historical models, and are therefore not as new as one might assume. But the widespread and global use of new financial instruments has contributed to the deployment of 'weapons of mass destruction' in financial terms. This applies to the securitizations of loans, for example. Single property loans, five, ten, fifty, five hundred or five thousand or more loans were collected as bonds of different risk content in order to pass them onto a buyer in a bespoke form matching the purchaser's requirements. The buyers were on the whole banks scouring the markets for derivatives and structured bonds. They bought them because they promised high returns. Some that had relatively low interest rates as the risk was low. Others promised high interest but they also contained a fairly high risk. In the end no one really knew for sure which loans were bundled in which bonds. In view of this negligence concerning the opacity of the system, this was countered by spreading the risks, making things easier for everyone: for when one spreads risks, everyone bears a smaller one. But this was not a spreading of risk, but rather a veiling of existing risks by making them unfathomable. Securitization was a method of developing structured bonds and artificially creating ratable goods. Something was loaded with value that was possibly worthless. No one was really sure.

Structured bonds were all the more abundant the more banks and other agents of financial markets used so called leverages. Leverage means that the monetary resources of a financial institution or a fund were complemented by borrowing cheap foreign capital, as the interest rates were low, in order to extend the field of activity considerably. The additional capital functions as a lever which enables the financial institutions to line their own pockets with more profit, to put it figuratively. This leverage is enormous. And from a microeconomic point of view it is quite rational. Yet, this rationality applies to individual institutions, and not to the system as a whole. For the system as a whole this leverage means that the primary liable equity capital, i.e. the assurance for all the loans made within the system, is less than the loans themselves, which leads to insufficient cover of the credit risks, if these occur. Precisely this happened. According to the calculations of Nouriel Roubini the US banking system owns about 1.400 billion dollars of equity capital but has a depreciation need of 1800 billion dollars due to leverage (Sueddeutsche Zeitung, January 29, 2009; Frankfurter Allgemeine Zeitung, January 28, 2009; Interview with Nouriel Roubini, in: Focus Money, February 4, 2009). In 
Germany 1.000 billion Euros worth of bad debt exceed the equity capital of less than 400 billion Euros. Not only individual banks, but the banking systems in the United States and Germany as a whole are effectively bankrupt. This highlights the systemic character of the present financial crisis.

What are the further innovations? These include the formation of conduits, special purpose entities for releasing from stock the risks of trading with structured bonds. Thus, they no longer affect the balance of accounts and therefore no equity capital is required to provide cover. Consequently the liable equity capital, which according to the Basel agreements (Basel I and Basel II) is supposed to provide assurance on loans, is now freed for new investments. If it then possible to transfer the conduits to offshore centres (in the Caribbean, or in Ireland or other European countries) then the investors manage to evade the revenue offices or at least obscure their dealings. Few or no taxes are paid and social and ecological charges are notable for their absence. This enables the investors to make double or treble the profit. All of this is approved by the rating agencies. These have, as we know today, provided structured bonds with a triple AAA rating to bonds, even though they were in fact bad assets. Eventually even Prime Minister Merkel urged that rating agencies should be nationalized or that a public European rating agency should be created, as the private rating agencies have turned out to be unreliable.

Further, the emission of so called Credit Default Swaps (CDS) belongs to the bundle of financial innovations since the liberalization of the financial markets of the past decade.-CDS, that is insurance contracts on loans and the bundled structured bonds already mentioned. One can virtually not go bust as the risk is taken over by the insurance companies. That insurance company selling many of CDS is AIG (American International Group), possibly the world's largest insurance company, which was facing bankruptcy in 2008 and had to be bailed out by the US Government at a cost of billions of dollars. We must therefore seriously ask the question whether the insurance companies are truly able to cover all risks, if these turn into insurance claims. A sum that is commonly suggested but has not been verified yet is that credit redemption agreements amount to 62.000 billion dollars, i.e. they exceed global GDP. As soon as the financial crisis engulfs the real economy, as soon as even large businesses meet financial difficulties, many of these Credit Default Swaps will be due, and then the question arises whether the insurance companies will really be able to meet the demands or will have to throw in the towel and declare bankruptcy. The largest global insurance company-AIG - was partly nationalized in September, as it was unable to provide cover for far lesser bad loans. 
These financial innovations are obviously part of a system that no one thought out with diabolical intent, but which contains all the necessary ingredients to effectively strangle the real economy. This means that not only financial losses result will have to be absorbed, but jobs are lost and the pressure on mass income and wages will increase.

\section{THE STATE AS THE 'IDEAL GENERAL BANKER'}

No wonder then that the praise of the liberal market, sung by liberalism and neoliberalism, suddenly sounds rather out of tune and increasingly fewer people are prepared to sing it. By necessity the state enters the scene and has to attempt to rescue what the social sciences call 'financially driven capitalism' out of the vale of crises, or at least to prevent it slithering further and further into it. By slight of hand neoliberal, finance-driven capitalism turns into a nationalized and state driven capitalism. The state, described by Friedrich Engels as the 'ideal universal capitalist',-as it adopts all the functions essential to the system that are not fulfilled by private enterprise as no profit is to be made,-becoming the ideal general banker'. Why is this so?

Globalization has indeed created free markets. In the European Union the different markets are largely free, but we do not have a global or international, not even a European Nation. On the European level the European Commission has access to less than 0,9 percent of the social product of the member states as a source of tax revenue. And now this weak European 'nation' is supposed to counteract or compensate the losses and depreciation needs that exceed thousands of billions of dollars by strong and therefore expensive investments. This will not work and thus recourse has to be taken to the nation state, which some neoliberal cynics would have liked to flush down the loo (these are the precise words chosen by an US American ideologue of neoliberalism). The state is to heal the disease caused by the effect of toxic assets. 'Toxic papers' sounds relatively harmless. Whoever sells toxic food will face imprisonment. If, however, someone sells toxic assets and makes a fat profit, then he receives praise and a bonus. Some have no qualms to take legal action to obtain their bonuses, although it is the taxpayer who has to pay for the state funds fed into the banking system to compensate for the disaster created by these overpaid stock brokers.

The state is called upon because the nation state has the power to levy taxes and can draw on financial resources the markets have no access to. These resources are the incomes of the citizens of the state in the form of national taxes-now the tax regime provides a money supply to the banking sector by ensuring national funding. The market demands of the banks in form of their interest and returns 
expectations are no longer covered by the banks and the bonds they guarantee have lost in value. The real surpluses of the debtors derived from the 'real' economy are not sufficient to cover the demands of the banking sector.

The state will have to play the role of ideal general banker, because in capitalist money society the financial system is, as it were, a public good and because the downfall of the financial system would have greater repercussions than just the collapse of some ailing banks, which might not be of disadvantage: many jobs would be lost in the process; small investors would lose some of their investments and if they tried to prevent this by joining a 'run' on the banks this would threaten social stability. Therefore a solution to the financial crisis must be found-no question about that. But whether this solution is to be achieved as proposed by the governments is something that requires public debate. For there are essentially three strategies that are being employed by the state:

The first strategy is the recapitalization of ailing banks. The state supplies the banks with fresh capital they require to cover the risks of toxic assets. In this case the state would have to take over the management of these banks as those providing the funds should also have a say in the running of the business and thus becoming co-owners. To this Steinbruck, who had previously claimed that Marx might have been right, adopts a contrary position: bankers can run the banks far better than politicians can. Quod erat demonstrandum. This argument is neither consistent nor is it transparent. If tax money is to be invested in banks and the state is to be turned into an ideal general banker then a responsibility of the state for the banking business follows from the above. The principle of transparency requires the owners to take part in the management of a business. This is the inevitable conclusion. Joseph Stiglitz states clearly: if the state provides funding to the banks and thus owns them without exercising control, then this is a step towards 'disaster'.

Secondly, the state provides debt guarantees. This happened in the USA with its 700 billion USD debt guarantee, a strategy also pursued by the German Government, which passed a 480 billion Euro debt guarantee for the banks. In other countries the strategy is the similar. Thus banks are provided with assurances that allow them to trade amongst each other and to provide loans to customers to get the credit market off the ground. The old adage according to which the warrantor is the one to be throttled needs to be kept in mind. We can only hope that this will not come into effect as it then would be the tax payers' money that would then be due. The European Central Bank in its November 2008 report shows that 21 percent of the GDP is being used for assurances. If these are due then the European citizens are 21 percent poorer in GDP terms-not a small 
sacrifice to safe the banks and bankers.

The third strategy of the ideal general banker is the creation of a so called 'bad bank', a bank that administers the toxic assets while allowing other banks with good assets to become good banks again. All then depends on how long this bank is intended to last and which market value is adopted for the bad assets. This attitude was a source of scorn for Emile Zola in his novel 'Money', commenting on the French financial marketeers of the nineteenth century. Those buying bad assets either had to be particularly sly or unscrupulous or they would inevitably lose out. For good reason were they called 'wet feet'.

It will not be possible to avoid financial claims to the real economy being written off. The state as ideal general banker would be successful if this were to take place in some ordered form so as not to dent the efficiency of the real economy. Particularly wily individuals think they will be able to solve the problem by encouraging economic growth and thus stimulating the efficiency of the real economy. The ideal general banker should metamorphose into an ideal general capitalist on the basis of a new and green Keynesianism. But this is where Marx's double nature of economic processes comes into play. We are not merely in the midst of a financial crisis but also within an energy crisis, a climate crisis, and a food crisis. The crises relating to the material and energy resources of capitalist societies cannot be overcome by an increase of real growth; on the contrary such growth very likely will accentuate them.

Therefore we will have to find a 'holistic approach', permitting us to reduce the financial demands by bringing them into line with the capacity of the real economy to produce surpls value and profit on capital while taking the ecological and social restraints into account. All this cannot happen over night, including the writing off of financial assets-albeit in a great crash. But a great crash is not to be recommended, neither in social, political, economic, or ecological terms. A solution cannot merely aim at the financial sector, but must include a restructuring and redimensioning of the real economy under ecological and social premises. A social discourse in which these problems are discussed is required, particularly as it will take its time. Short-term and immediate solutions are no doubt required. But we will also require sufficient stamina to think beyond capitalism as we know it today to develop and try out alternatives.

Texto submetido à Revista em 19.11.2008 e aceito para publicação em 14.5.2009. 